\title{
16S rRNA and hydrazine gene-based profiling of the Candidatus Scalindua community from the Arabian Sea hypoxic sediments
}

\author{
Jovitha Lincy* and Cathrine Sumathi Manohar \\ Biological Oceanography Division, CSIR-National Institute of Oceanography, Goa 403 004, India and \\ Academy of Scientific and Innovative Research, Ghaziabad 201002 India
}

\begin{abstract}
Anammox bacterial diversity and abundance were studied from the organic-rich hypoxic sediments of the Arabian Sea utilizing the partial 16S rRNA, and hydrazine synthase, hzsA and hydrazine oxidoreductase, hzo genes. Among all the clades obtained, phylotypic diversity was high within the Candidatus genus Scalindua with an abundance of $\leq 7 \times 10^{4}$ copies $/ g$ dry wt. As such, Scalindua is known to play a significant role in fixed nitrogen removal through anaerobic ammonium oxidation (anammox) pathway. From these analyses, it is inferred that searching for hzo gene yields robust evidence for detecting anammox community than the widely used 16S rRNA gene marker.
\end{abstract}

Keywords: Anammox, community gene-based profiling, hydrazine, hypoxic sediments, Scalindua.

THE oxygen-depleted zones (ODZs) are important sites of fixed nitrogen loss, as the scarcity of oxygen, a primary electron acceptor, leads to increased utilization of the next preferred electron sources ${ }^{1}$. Anaerobic ammonium oxidation (anammox) and denitrification are the two major microbial pathways operating in such an environment which are responsible for nitrogen removal ${ }^{2}$. One of the questions being examined in the perennial ODZ localized within the Arabian Sea and the eastern tropical north and the South Pacific Ocean is whether anammox is dominant over denitrification ${ }^{2,3}$, and is chiefly inquired utilizing chemical signatures. The anammox reaction, in general, requires ammonia $\left(\mathrm{NH}_{4}^{+}\right)$and nitrite $\left(\mathrm{NO}_{2}^{-}\right)$as substrates in a stoichiometric ratio of approximately $1: 1$ and proceeds via two intermediates, nitric oxide (NO) and hydrazine $\left(\mathrm{N}_{2} \mathrm{H}_{4}\right)$, and releases di-nitrogen gas $\left(\mathrm{N}_{2}\right)^{4}$. Understanding molecular pathways of anammox reactions led to gene-targeted studies, which further made anammox bacterial identification and quantification possible even at species level ${ }^{5,6}$. Yet such information is not utilized properly, and those who attempted molecular characterization have limited themselves to one or two primer sets alone, that too without considering the primer bias.

\footnotetext{
*For correspondence. (e-mail: jovithalincy@gmail.com)
}

The nitrogen loss contribution of anammox to the total denitrification in marine sediments can range from near $0 \%$ to $80 \%$, especially in deposits underlying $\mathrm{ODZ}^{7}$. In the southeastern Arabian Sea, benthic nitrogen metabolism is driven by sinking organic matter ${ }^{8}$ which is exceptionally high during the southwest monsoon period ${ }^{9}$. The prevailing conditions are assumed to favour heterotrophic denitrifying communities that rely on organic sources ${ }^{10}$. Hence the possible occurrence of a chemolithoautotroph like anammox microbes is not studied thoroughly. Besides ammonium ion available in situ ${ }^{11}$, dissimilatory nitrate reduction to ammonia (DNRA) is reported ${ }^{1}$. In the Oman coast of the Arabian Sea, a coupling of DNRA to anammox resulted in intense nitrogen loss ${ }^{12}$, suggesting that anammox occurrence is controlled by the availability of substrates, and the dominance of denitrifiers, in particular, cannot limit anammox bacterial abundance in ODZ .

In comparison to the denitrifying microbial community, little is known about the anammox community. All identified anammox clades have monophyletic origin and are classified under bacterial phylum Planctomycetes and order 'Brocadiales'" . To date, seven anammox genera are reported ${ }^{13-19}$ : Ca. Brocadia, Ca. Kuenenia, Ca. Scalindua, Ca. Anammoxoglobus, Ca. Jettenia, Ca. Brasilis and Ca. Anammoximicrobium (placed under separate order Pireullulaceae). Genus Scalindua is the most diverse as well as the dominant anammox community identified in the marine environment. It is characterized as a separate sub-group, as its distribution is primarily governed by high salinity ${ }^{20}$. The phylogenetic $16 \mathrm{~S}$ rRNA marker gene and functional markers targeting hydrazine genes, a biomarker unique to anammox reaction, have been successfully applied and tested in various habitats to understand the anammox community structure ${ }^{5,21,22}$.

In the present study, we utilized five well-established, highly specific anammox-specific primer sets to target partial 16S rRNA, hydrazine synthase gene subunit A (hzsA) and hydrazine oxidoreductase gene (hzo). The functional gene primers are known to target both Scalindua and non-Scalindua anammox communities, whereas the 16S rRNA primer specifically targets the Scalindualike anammox community. We screened for multiple 
Table 1. Details of PCR primers used in the present study

\begin{tabular}{|c|c|c|c|c|c|c|}
\hline Gene target & Use & Primer & Sequence & Reference & Base pair & $\begin{array}{l}\text { Primary melting } \\
\text { temperature }\end{array}$ \\
\hline Scalindua $16 \mathrm{~S}$ rRNA & Clone library & $\begin{array}{l}\text { Brod541F } \\
\text { Brod1260R }\end{array}$ & $\begin{array}{l}\text { GAGCACGTAGGTGGGT TTGT } \\
\text { GGATTCGCTTCACCTCT CGG }\end{array}$ & 29 & 719 & 59 \\
\hline Anammox $h z o$ & Clone library & $\begin{array}{l}\text { HZOF1 } \\
\text { HZOR1 }\end{array}$ & $\begin{array}{l}\text { TGTGCATGGTCAATTG AAAG } \\
\text { CAACCTCTTCWGCAGG TGCATG }\end{array}$ & 30 & 1000 & 53 \\
\hline Anammox 16S rRNA & qPCR & $\begin{array}{l}\text { Brod541F } \\
\text { Amx } 820 \mathrm{R}\end{array}$ & $\begin{array}{l}\text { GAGCACGTAGGTGGGT TTGT } \\
\text { AAAACCCCTCTACTTAGTGCCC }\end{array}$ & 33 & 279 & 60 \\
\hline Anammox $h z s \mathrm{~A}$ & qPCR & $\begin{array}{l}\text { hzA1597F } \\
\text { hzA1857R }\end{array}$ & $\begin{array}{l}\text { WTYGGKTATCARTATG TAG } \\
\text { AAABGGYGAATCATAR TGGC }\end{array}$ & 5 & 261 & 60 \\
\hline $\begin{array}{l}\text { hzo_cluster2 for } \\
\text { non-Scalindua }\end{array}$ & qPCR & $\begin{array}{l}\text { hzocl2aF } \\
\text { hzocl2aR1 }\end{array}$ & $\begin{array}{l}\text { GGTTGYCACACAAGGC } \\
\text { TYWACCTGGAACATAC CC }\end{array}$ & 32 & 289 & 60 \\
\hline Cloned gene fragment & Sequencing PCR & $\begin{array}{l}\text { M13F } \\
\text { M13R }\end{array}$ & $\begin{array}{l}\text { GTTTTCCCAGTCACGA C } \\
\text { CAGGAAACAGCTATG AC }\end{array}$ & 59 & Variable & 50 \\
\hline
\end{tabular}

genes to assess phylotypic diversity of anammox community, including the genus Ca. Scalindua using multiple sets of primers that targeted to amplify functional (anammox-specific) and ribosomal (taxonomy-specific) fragments and are assumed to occur in high diversity and abundance in oxygen-depleted, organic-rich surface sediments of the southeastern Arabian Sea. In parallel, we also tested the possible occurrence of non-Scalindua anammox community. To our knowledge, there are no previous reports from the benthic ODZ of the Arabian Sea exclusively targeting Scalindua, a dominant anammox bacterial genus.

\section{Materials and methods}

\section{Sampling details}

The sediment sample was collected during the SSD-014 cruise of $R V$ Sindhu Sadhana from the Arabian Sea at around $600 \mathrm{~m}$ water-column depth $\left(9^{\circ} 57^{\prime} \mathrm{N}, 75^{\circ} 32^{\prime} \mathrm{E}\right)$. Sampling was carried out in September 2015, which marks the end of the southwest monsoon period. The Van Veen Grab sampler was used for sediment sample collection. The samples were handled aseptically and preserved at $-20^{\circ} \mathrm{C}$ until further analysis. Temperature and salinity profiling of the sampling location was carried out using a Sea-Bird Electronics CTD (conductivity-temperaturedepth; model SBE9), fitted with Niskin/Go-Flo bottles. The dissolved oxygen (DO) profile of the location was also obtained using a calibrated sensor (RINKO from ALEC, Japan) attached to the CTD unit.

\section{Chemical characterization of sediment}

The sediments were freeze-dried, homogenized and ground to a fine powder in an agate mortar before analysis. Total carbon (TC) and total nitrogen (TN) were analysed using a CN analyser (FISONS NA1500) ${ }^{23}$. Total organic carbon (TOC) was determined using a colorimetry-based wet oxidation method with high reproducibility ${ }^{24}$. Total inorganic carbon (TIC) was estimated by subtracting $\mathrm{OC}$ from $\mathrm{TC}^{25}$. To estimate organic matter (OM), TOC was multiplied by Van Bemmelen's factor 1.724 , based on the assumption that humidified $\mathrm{OM}$ of the soil contains $58 \%$ carbon, but it could vary from $40 \%$ to $60 \%$ (ref. 26). For $\mathrm{CaCO}_{3}$ calculation, TIC was multiplied by 8.33 to obtain the relative percentage ${ }^{25}$. The OC/TN ratio was converted into molar ratio by multiplying with a factor 1.167 , derived from the atomic weights of nitrogen and carbon ${ }^{27}$.

\section{Metagenomic analysis}

Total genomic DNA was extracted from $500 \mathrm{mg}$ of the freeze-dried sediment samples using the Fast $\mathrm{DNA}^{\mathrm{TM}}$ SPIN Kit for Soil (MP Biomedicals, Santa Ana, CA, USA), and for cell lysis the Fastprep 24 cell disruptor was used based on the manufacturer's instructions. Fastprep is one of the most successful and efficient sediment DNA extraction methods that yields reasonably good DNA quality and quantity ${ }^{28}$. The purified DNA was quantified using a nanodrop 2000 spectrophotometer (ThermoScientific, USA) and visualized on an agarose gel $(0.8 \%)$ to determine the quality of the extracted DNA. The gel was viewed using the AlphaImager Gel documentation system after staining with ethidium bromide (EtBr). PCR was carried out using Scalindua-specific 16S rRNA primer set, Brod541F/Brod1260R (ref. 29) and anammox primer set HZOF1/HZOR1 for hydrazine oxidoreductase gene ${ }^{30}$. Table 1 lists the primers used in the present study. The PCR conditions maintained were as follows: initial denaturation at $95^{\circ} \mathrm{C}$ for $5 \mathrm{~min}, 35$ cycles of denaturation: $94^{\circ} \mathrm{C}$ for $60 \mathrm{sec}$, annealing temperature was $59^{\circ} \mathrm{C}$ for $16 \mathrm{~S}$ rRNA and $53^{\circ} \mathrm{C}$ for $h z o$ genes for $60 \mathrm{sec}$, extension: $72^{\circ} \mathrm{C}$ for $90 \mathrm{sec}$, followed by a final extension at $72^{\circ} \mathrm{C}$ for $10 \mathrm{~min}$. The PCR reaction was carried out in a $0.2 \mathrm{ml}$ reaction tube in a final volume of 
$50 \mu 1$. The reaction mix contained $1 \times$ PCR buffer, $1.5 \mathrm{mM} \mathrm{MgCl}_{2}, 10 \mathrm{mM}$ dNTPs, $10 \mathrm{pM}$ each of forward and reverse primers, and $0.32 \mathrm{U}$ of Taq polymerase enzyme. About $1 \mathrm{ng}$ of template DNA that was diluted to 0.1-0.2 ng/ $\mu \mathrm{l}$ was used. All PCR components were purchased from Genei, Bangalore.

PCR products were purified prior to TA (thymineadenine) cloning using the GenElute ${ }^{\mathrm{TM}}$ PCR clean-up kit (Sigma-Aldrich, USA) and quantified. Cloning was performed using the pGEM ${ }^{\circledR}-\mathrm{T}$ Easy Vector System (Promega, USA) based on the manufacturer's instructions. Positive recombinant was screened using the X-gal-IPTG LB indicator plate amended with $100 \mu \mathrm{g} / \mathrm{ml}$ ampicillin. The transformation efficiency for anammox hzo and $16 \mathrm{~S}$ Scalindua was $9 \times 10^{7}$ and $1.9 \times 10^{8} \mathrm{cfu} / \mu \mathrm{g}$ DNA respectively. Plasmid extraction was performed using GenElute $^{\mathrm{TM}}$ Plasmid Miniprep kit (Sigma-Aldrich, USA). Insert size was checked using M13F/M13R primer as well as targeted primers. The positive clones were sequenced using ABI 3130XL genetic analyzer (Applied Biosystems, USA).

\section{Sequence analysis and processing}

Sequence quality was checked using SeqScanner software v.1.0 (Applied Biosystems, USA), 2005. Good-quality sequences were further screened for vector contamination through the NCBI VecScreen portal (https://www.ncbi. nlm.nih.gov/tools/vecscreen/) and edited using BioEdit software v.7.2.6.1. Sequence similarity search was carried out using the NCBI BLAST algorithm. Misaligned sequences were corrected using sequence massager online (http://biomodel.uah.es/en/lab/cybertory/analysis/massager. $\mathrm{htm})$. Chimera check was performed during the sequence submission step at GenBank. Most similar hits, as well as standard reference sequences, were included for phylogenetic tree construction. Sequences with a length of $\geq 500 \mathrm{bp}$ were used for diversity and phylogenetic analysis. The sequences were aligned using CLUSTAL-W multiple sequence alignment tool in BioEdit software v.7.2.6.1. The phylogenetic tree was constructed using MEGA X software neighbour-joining method with 1000 bootstrap replicates. For functional genes, the nucleotide sequences were first translated to amino acids through the ExPASY online portal (https://web.expasy.org/translate/) prior to detailed analysis.

\section{Statistical analysis}

Clones were clustered into operational taxonomic units (OTUs) using Mothur v.1.35.1 after generating a distance matrix in BioEdit v.7.2.6.1. A 97\% similarity cut-off was used for genus-level clustering. For Scalindua $16 \mathrm{~S}$ rRNA, $0.5 \%$ distance was chosen and for hzo (gene-translated protein sequence) $1 \%$ distance was used ${ }^{6}$. Coverage of clone library was calculated as $C=\left[1-n_{i} / N\right] \times 100$, where $n_{i}$ is the total number of organisms of each species and $N$ is the total number of organisms of all species. For diversity calculation, Shannon $\left(H^{\prime}\right)$ and Simpson $\left(D^{\prime}\right)$ diversity indices were used. Pielou's index $\left(\mathrm{J}^{\prime}\right)$ was used to understand species evenness. For species richness, abundance-based coverage estimator $\left(S_{\mathrm{ACE}}\right)$ and evenness biascorrected $\left(S_{\text {Chao } 1}\right)$ were used. For diversity estimation, statistical software Primer v.6.1.10 and Estimate S v.9.1.0 were used.

\section{Quantification of anammox genes}

For qPCR-based gene quantification, three anammoxspecific genes were targeted: $16 \mathrm{~S}$ rRNA, hzsA and hzo_cluster ${ }^{2}$. Primer pair Brod541F/Amx820R used for $16 \mathrm{~S}$ rRNA gene is known to target all environmental anammox clusters ${ }^{30}$. However, previous studies reveal that this primer set amplifies only genus Scalindua ${ }^{31}$. The functional genes specifically targeted $h z s \mathrm{~A}$ common to all known anammox communities ${ }^{5}$ and non-Scalinduaspecific hzo_cluster2 gene $^{32}$. The gene target size varied between 260 and $290 \mathrm{bp}$ for qPCR estimation, while primers used for diversity studies targeted a 720 and $1000 \mathrm{bp}$ fragment, making it not suitable for qPCR-based gene quantification as it generates non-specific fluorescence. The specificity of plasmid clones prepared for the standard curve was checked using BLAST search, and clones with maximum similarity were only used (MG687445 (100\%), MG687463 (96\%), and MG687465 $(83 \%))$. These plasmid standards were generated from the ODZ surface sediments underlying $200 \mathrm{~m}$ water-column depths of the Arabian Sea, off Goa site. Standard curves were determined by analysing ten-fold serial dilutions of linear plasmid containing an insert of choice, with linear regression of $C_{\mathrm{T}}$ values plotted against an initial copy number on a $\log$ scale from $10^{-1}$ to $10^{-8}$. Amplification factor and PCR efficiency were calculated from the slope using qPCR efficiency calculator available on-line (ThermoFisher, USA). The qPCR was performed in triplicate in $20 \mu \mathrm{l}$ final reaction volume containing $1-1.25 \mathrm{ng}$ of sediment-extracted DNA diluted to $0.2 \mathrm{ng} / \mu \mathrm{l}, 10 \mu \mathrm{l}$ of 2X Sybr fast master mix (Kapa Biosystems, USA), 1X ROX reference dye (low), 10 pmol each of forward and reverse primers on a 7500 Fast-Real-Time PCR system (Applied Biosystems, CA, USA). The PCR programme was initiated with a denaturation step spanning $15 \mathrm{~m}$ at $95^{\circ} \mathrm{C}$, followed by 40 cycles of $95^{\circ} \mathrm{C}$ for $15 \mathrm{sec}, 60^{\circ} \mathrm{C}$ for $60 \mathrm{sec}$ and $72^{\circ} \mathrm{C}$ for $30 \mathrm{sec}$. Fluorescence was detected at PCR extension at $72^{\circ} \mathrm{C}$. Melt curve analysis was performed at the end of 40 cycles to check the specificity of amplification. Gel electrophoresis confirmed that only the right size fragment was amplified. The gene copy number was calculated from the $C_{\mathrm{T}}$ value applied to the regression formula generated from the standard curve (log 


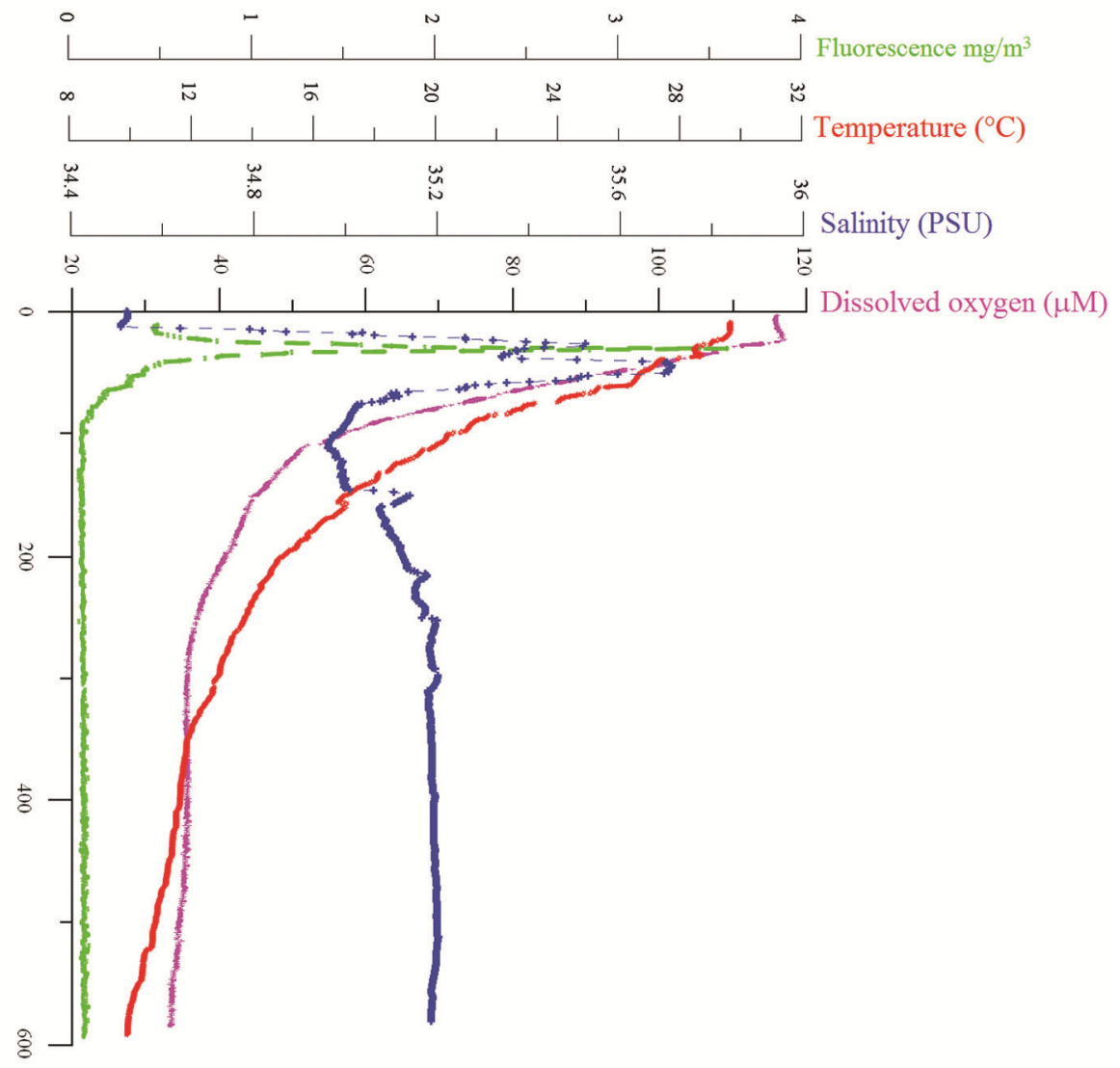

Figure 1. CTD profile of K-600 station showing water column physico-chemical characteristics of the sampled site.

Table 2. Sample characteristics of K-600 station

\begin{tabular}{|c|c|c|c|c|c|c|c|c|c|c|}
\hline \multirow[b]{2}{*}{ Sampling date } & \multirow[b]{2}{*}{ Station } & \multicolumn{4}{|c|}{ Sediment characteristics (\%) } & \multirow[b]{2}{*}{$\mathrm{TOC} / \mathrm{TN}$} & \multicolumn{3}{|c|}{ Near bottom water profile } & \multirow[b]{2}{*}{ Depth (m) } \\
\hline & & TOC & TIC & $\mathrm{TN}$ & $\mathrm{OM}$ & & $\mathrm{DO}(\mu \mathrm{M})$ & Temperature $\left({ }^{\circ} \mathrm{C}\right)$ & Salinity (PSU) & \\
\hline 15 September 2015 & $\mathrm{~K}-600$ & 4.662 & 7.131 & 0.906 & 8.037 & 6.005 & 33.05 & 9.945 & 35.188 & 580 \\
\hline
\end{tabular}

scale). Copy number calculations were made per nanogram of DNA, and results were expressed per gram weight of sediment.

\section{GenBank accession number}

Nucleotide accession numbers for anammox-specific clone library obtained are as follows: Scalindua16S rRNA library (MG586106-MG586157) and Scalindua HZO library (MG687469-MG687487).

\section{Results}

\section{Site characteristics}

The CTD profile indicates that the near-bottom water (584 m) DO was $\sim 33 \mu \mathrm{M}$, which implies stronger hypoxia in the underlying sediments (Figure 1). The bottomwater temperature was $9.95^{\circ} \mathrm{C}$ and salinity (35.19 PSU) coincided with the average value for the Arabian Sea. The sediment samples had high OC (4.662\%) and exceptionally high TN $(0.906 \%)$. The TIC was also found to be very high $(7.13 \%)$, along with high OM $(8.04 \%)$. The observed TOC/TN ratio of 5.14 is common to off shore sediment samples (Table 2).

\section{Scalindua $16 S$ rRNA gene diversity and phylogeny}

The 16S rRNA primer set used (Brod541F/Brod1260R) is highly specific to Scalindua, and hence all clones obtained using this primer in the study shared maximum similarity with known Scalindua sp. only (Figure 2). These sequences were $95-99 \%$ identical to each other and 98-100\% identical to the top hits in GenBank sequences. Almost $90 \%$ of the sequences obtained shared similarities with a wide range of marine sediment habitats. This covers oceanic regions that include Chuckchi Sea (Arctic Ocean), Antarctic Sea (Southern Ocean), 


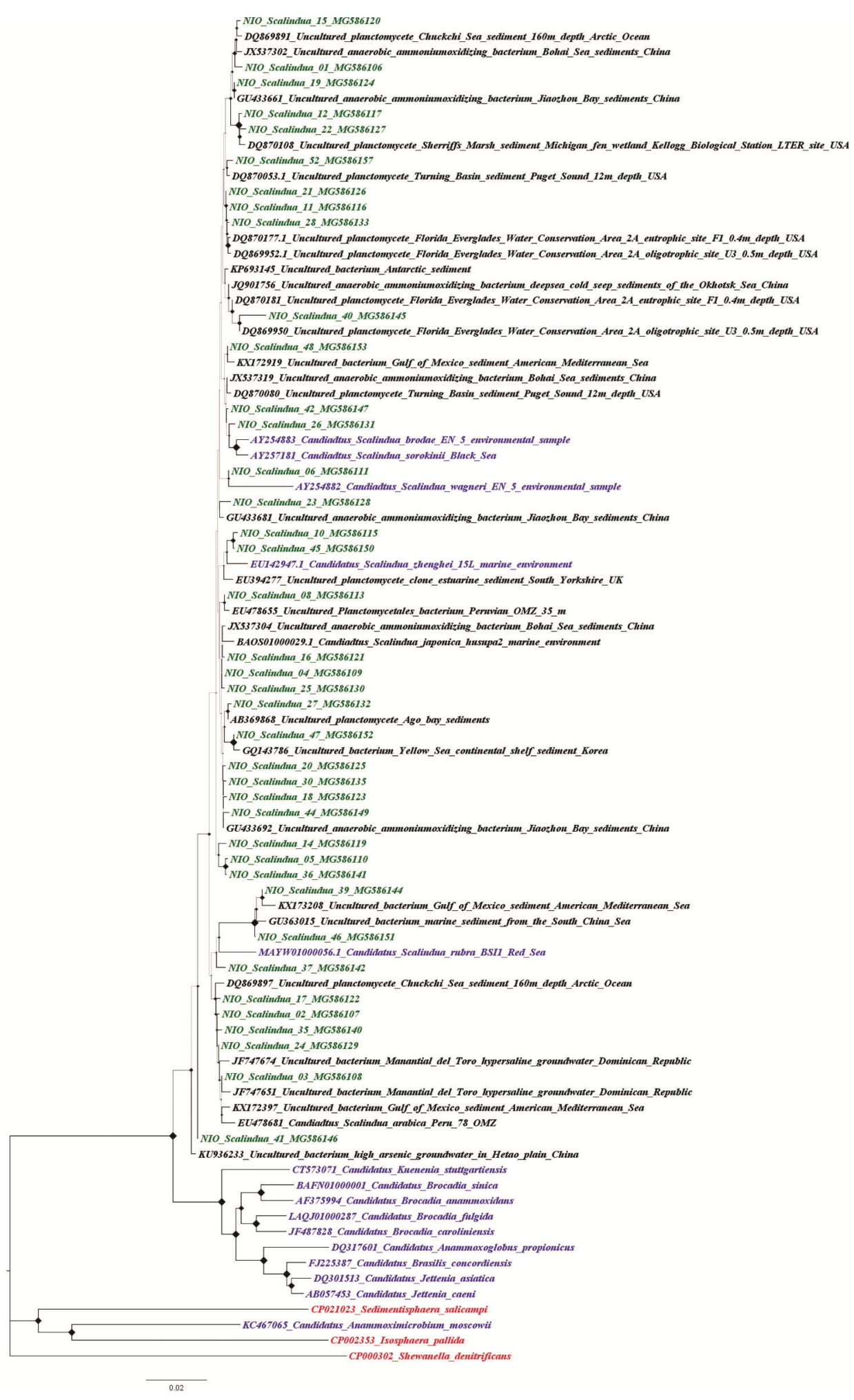

Figure 2. 16S rRNA gene-based phylogenetic tree of Scalindua anammox community from surface sediments of the eastern Arabian Sea underlying $600 \mathrm{~m}$ deep water column. Primer pair Broad541F/Brod1260R was used for clone library construction, which is known to target only Scalindu sp. Neighbor-joining tree was reconstructed taking 1000 bootstrap replicates. Clones are in green colour, anammox reference sequence in blue colour and outgroups in red colour. The most similar hits are in black colour. The evolutionary distances were computed using the maximum composite likelihood method and are in the units of the number of base substitutions per site. This analysis involved 87 nucleotide sequences. All ambiguous positions were removed for each sequence pair (pairwise deletion option). There was total of 2275 positions in the final dataset. Evolutionary analyses were conducted in MEGA X. Bootstrap support is shown in the phylogenetic tree, which corresponds to node diameter and branch width. 
RESEARCH ARTICLES

Table 3. Diversity analysis of phylogenetic and functional gene clone library

\begin{tabular}{|c|c|c|c|c|c|c|c|c|c|c|}
\hline Target gene & $N$ & Similarity (\%) & OTU & Coverage & Alpha diversity & $J^{\prime}$ (evenness) & $H^{\prime}$ (Shannon) & $D^{\prime}$ (Simpson) & $S_{\mathrm{ACE}}$ & $S_{\text {Chaol }}$ \\
\hline \multirow{3}{*}{$\begin{array}{l}\text { Scalindua } 16 \mathrm{~S} \\
\text { rRNA }\end{array}$} & \multirow[t]{3}{*}{39} & 99.5 & 26 & 33.33 & 6.824 & 0.9479 & 3.088 & 0.031 & 71.95 & 59.32 \\
\hline & & 99 & 15 & 61.54 & 3.821 & 0.9089 & 2.461 & 0.085 & 19.86 & 16.62 \\
\hline & & 97 & 02 & 94.87 & 0.273 & 0.2918 & 0.2023 & 0.90013 & 2 & 2 \\
\hline \multirow[t]{2}{*}{ Anammox hzo } & \multirow[t]{2}{*}{17} & 99 & 17 & 0 & 5.647 & 1 & 2.833 & 0 & 145 & 145 \\
\hline & & 97 & 14 & 17.65 & 4.588 & 0.9692 & 2.558 & 0.0294 & 63.92 & 43.05 \\
\hline
\end{tabular}

Jiaozhou Bay of the Yellow Sea located in South China and Mie, Ago Bay in Japan (Indian Ocean), West of Juan de Fuca Ridge and Peruvian oxygen minimum zone (OMZ) (Pacific Ocean) and Gulf of Mexico (Atlantic Ocean). Around $10 \%$ of sequences shared similarity with those retrieved from hypersaline groundwater, marshy areas, turning basin, and water conservation areas. Our result displays high diversity in the benthic Scalindua community in the sampled site of the Arabian Sea (Table $3)$. After removal of short-length sequence $(\leq 500 \mathrm{bp})$, only 39 out of 52 sequences were subjected to further analysis. A total of 26 out of 39 Scalindua-specific $16 \mathrm{~S}$ rRNA OTUs were obtained at a $0.05 \%$ sequence dissimilarity distance cut-off; the corresponding $H^{\prime}$ index was 3.09 and predicted OTUs were 60.

\section{Phylotypic diversity and phylogeny of hzo gene fragment}

The HZOF1/HZOR1 primer pair-based clone library had 19 positive clones out of 27 total sequences. Their similarity in the positive clones ranged from $94 \%$ to $99 \%$ with the hzo sequences in GenBank. In 17 of these 19 positive hzo clones, similarity ranged between $84 \%$ and $98 \%$. Two sequences were eliminated due to their shorter than $500 \mathrm{bp}$ length. These 17 clones formed 14 distinct OTUs at $97 \%$ sequence similarity cut-off (Figure 3). At $99 \%$ cut-off, all fell out as separate OTUs. As much as $65 \%$ of the sequences clustered into clades bearing similarities with hzo sequences retrieved from Soledad basin OMZ sediments and South China Sea sediments. $H^{\prime}$ was 2.83 with a higher estimated richness of $\sim 145$.

\section{Anammox gene copy number estimation}

Anammox abundance on an average was $10^{4}$ copies per gram dry weight of sediment irrespective of the genes targeted. The PCR efficiency for various anammoxspecific genes used here ranged from $102 \%$ to $110 \%$. The necessary correction was done to get an amplification factor of 2 before estimating copy number, which was expressed per gram of sediment and per nanogram of total DNA. The Scalindua 16S rRNA, anammox hzsA and non- Scalindua hzo_cluster2 copy numbers were $6.89 \pm 0.14 \times 10^{4}, 4.99 \pm 0.35 \times 10^{4}$ and $3.53 \pm 0.33 \times 10^{4}$ copies per gram of sediment and 9.4, 6.8 and 4.8 copies/ng of DNA respectively.

\section{Discussion}

Majority of the studies related to anammox bacterial abundance and diversity from the Indian Ocean are from pelagic $\mathrm{ODZ}^{33,34}$ and decidedly less information is available from sediment $\mathrm{ODZ}^{35,36}$, which is limited to $16 \mathrm{~S}$ rRNA gene alone. The present multi-primer approach was useful to make realistic estimates of anammox abundance and ascertained the need for using multiple gene markers for reliable quantification of functional and phylotypic members of the anammox process ${ }^{37}$. All the primers used in the present study were able to amplify in single PCR consisting of 35-40 cycles, suggesting quite a high abundance of anammox microbes off Kochi hypoxic zones. In the following discussion, to avoid primer bias and for habitat specificity, the studies emanating from marine environment were carried out utilizing the same primer set only considered.

\section{The Arabian Sea hypoxic zone characteristics}

The Arabian Sea is one of the most productive regions of the world's oceans and sediments underlying it are reported to have high OM content ${ }^{38}$. Sampling was carried out during the southwest monsoon period when productivity is the highest ${ }^{39}$. High productivity in surface water and subsequent settling of OM lead to the consumption of DO, and eventually results in the build-up of hypoxia and subsequent alteration of microbial communities $^{40}$. The average percentage TOC and TN values reported from deep-sea sediments of the Gulf of Mexico were $0.9 \pm 0.3$ and $0.12 \pm 0.03$ respectively ${ }^{41}$ and the maximum reported $\mathrm{TOC}$ is $14.5 \%$ and $\mathrm{TN}$ is $1.6 \%$ in OMZ surface sediments ${ }^{42}$. Here the sediment TOC and $\mathrm{TN}$ were $4.67 \%$ and $0.9 \%$ respectively, owing to high productivity-induced hypoxia leading to rapid burial of TOC and $\mathrm{TN}^{43}$. After oxygen, as nitrogen is the next preferred electron acceptor, facultative anaerobes relying on processes like anammox and denitrification dominate in the $\mathrm{ODZ}^{1}$. In pelagic ecosystem DO and salinity are the major factors controlling the distribution of Scalindua ${ }^{20}$, whereas in benthic ecosystem their abundance is affected 


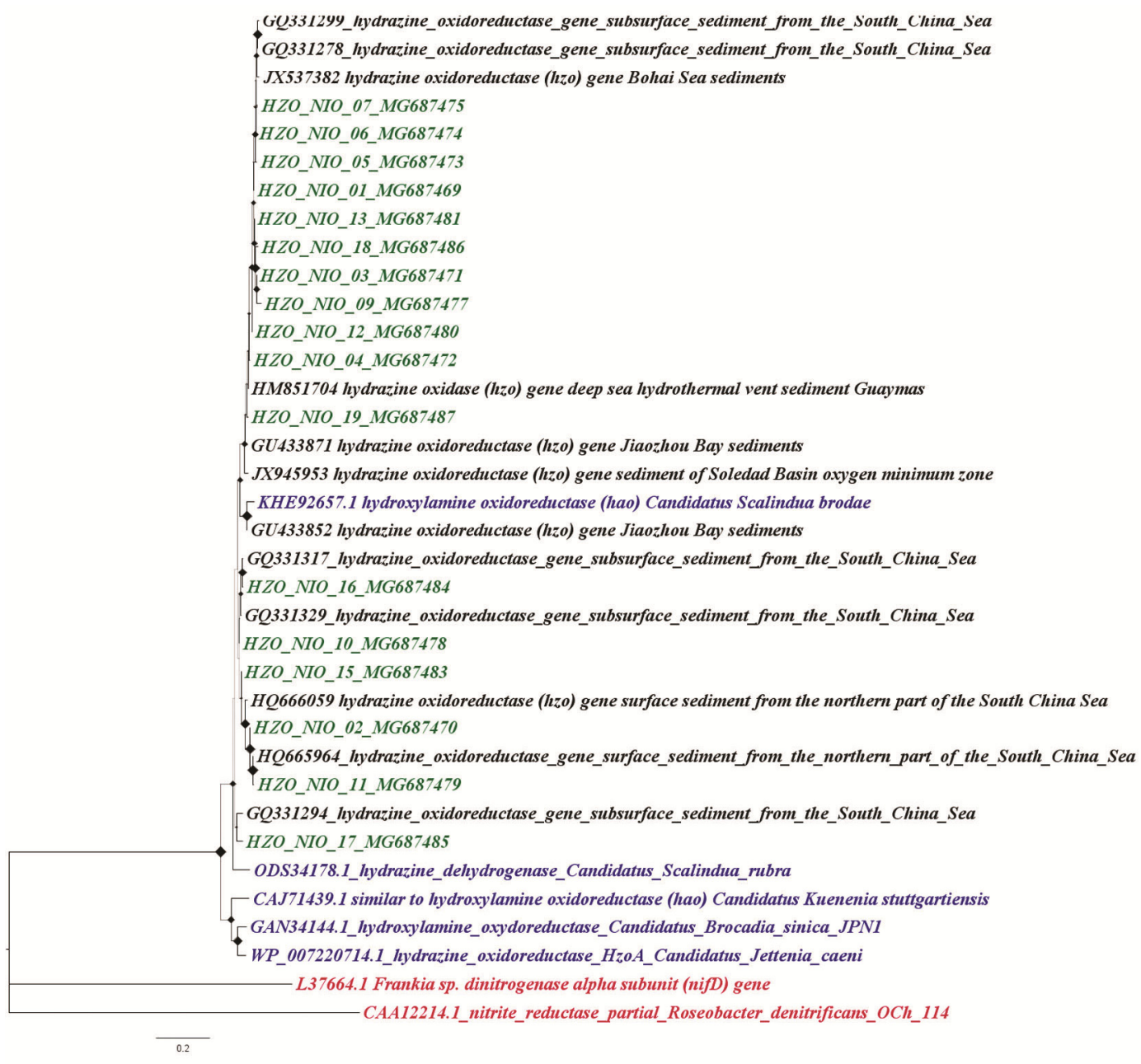

Figure 3. Hydrazine oxidoreductase, hzo gene-based phylogenetic tree of anammox community from surface sediments of the eastern Arabian Sea underlying $600 \mathrm{~m}$ deep water column. Primer pair HZOF1/HZOR1 was used for clone library construction, which is known to target all known anammox groups. Neighbour-joining tree was reconstructed, taking 1000 bootstrap replicates. Clones are represented in green colour, anammox reference sequence in blue colour and outgroups in red colour. The most similar hits are in black colour. The evolutionary distances were computed using the Poisson correction method and are in the units of the number of amino acid substitutions per site. This analysis involved 36 amino acid sequences. All ambiguous positions were removed for each sequence pair (pairwise deletion option). There was a total of 673 amino acid positions in the final dataset. Evolutionary analyses were conducted in MEGA X. Bootstrap support is shown in the phylogenetic tree, which corresponds to node diameter and branch width.

by sediment TOC and $\mathrm{TN}$ content ${ }^{44}$, particularly the availability of nitrogenous substrate nitrite and ammonia $^{12}$. Here the near-bottom DO was higher than amiable; however, there is a possibility that the sediment anammox community must have restricted itself to anoxic microniches as seen in pelagic $\mathrm{ODZ}^{33}$.

\section{Anammox gene phylogeny and diversity}

Scalindua is reported to be a low diverse community in the Arabian Sea pelagic ODZ ${ }^{45}$. In this study, we observed higher diversity and the obtained clones shared $\sim 99 \%$ similarity with all seven marine Scalindua species previously reported ${ }^{15,46-49}$. These are $S$. sorokinii, $S$. brodae, S. arabica, S. wagneri, S. zhenghei and S. rubra. A similar study carried out using the sediment samples from Bohai Sea, had recovered a maximum of only 15 Scalin$d u a$-specific OTUs, but $24 \mathrm{hzo}$-specific OTUs at $0.5 \%$ and $1 \%$ cut-off $^{6}$. In the present studies, we obtained 26 Scalindua-specific 16S rRNA OTUs and 17 hzo-specific OTUs at the respective cut-off values. However, predicted abundance for $h z o$ is higher in this study, suggesting that the anammox community in the Arabian Sea sediments might be much more diverse.

Shannon diversity index $\left(H^{\prime}\right)$ was 3.078 and 2.994 for the two targeted genes respectively, while in Bohai Sea sediments, the values ranged between 1.46 and $2.95 ; 2.18$ 
and 3.79 for $16 \mathrm{~S}$ rRNA and hzo genes respectively. In Bohai Sea sediment, another interesting observation was that in samples where hzo diversity was high, the Scalindua 16S rRNA diversity was low, i.e. 1.46/3.79 and when Scalindua 16S rRNA diversity was high, there was not much difference in the diversity of hzo gene $(2.95 / 2.85)^{6}$. Similarly, in this study, diversity index for the two genes did not vary much, suggesting that the hzo sequences recovered in this study most likely belongs to Scalindualike anammox community. This is reflected in the phylogenetic analysis as well, as hzo sequences clustered only with Scalindua sp. Similar results were also reported from the highly productive Peru margin ODZ sediments ${ }^{50}$.

This study highlights the need to use primer sets to amplify both taxonomic and functional gene fragments. In spite of the fact that abundance in terms of copy numbers was low, the use of hzo primers confirmed the presence of anammox community mostly comprising Scalindua OTUs. Using Planctomycetes-specific forward and universal bacterial reverse primers ${ }^{35}$, six Scalindua OTUs were reported from surface sediments off Kochi ${ }^{51}$. Apparently, looking for specific functional gene $/ \mathrm{s}$ involved in the anammox process would prove useful in future studies for detecting the community involved as well as for confirming the occurrence of anammox simultaneously with other denitrification reactions.

Hydrazine gene markers are highly unique to the anammox community, and many primers have been successfully tested in diverse habitats targeting hydrazine subunits, namely synthase $(h z s)$ and oxidoreductase $(h z o)$ genes $^{5,32}$. Recent studies identify the occurrence of hydroxylamine oxidoreductase (hao) and hydroxylamine dehydrogenase $(h d h)$ as well as hydrazine hydrolase $(h h)$ genes in selected species, and primers have been developed using the sequence information ${ }^{52}$. The hzo primer set used for this analysis was able to amplify a $\sim 1000 \mathrm{bp}$ gene fragment, thus making it useful for phylogenetic analysis $^{30}$. Similar to $16 \mathrm{~S}$ rRNA gene, majority of the hzo gene sequences also shared similarities with those obtained from surface/subsurfaces sediments of the South China Sea and Soledad Basin sediments.

\section{Anammox gene abundance}

From North Sea sediments, maximum gene abundance reported for $h z s \mathrm{~A}$ ranged between $10^{5}$ and $10^{6}$, and for the $16 \mathrm{~S}$ rRNA gene a ten-fold increase was reported at shallow depth ${ }^{53}$. Phylogeny studies confirmed that all clones were similar to Scalindua only. While another study from the same location carried out in sandy and muddy shelf sediments reported anammox copy number as low as $10^{3}$ for $16 \mathrm{~S}$ rRNA, whereas $h z s \mathrm{~A}$ was below detection limit ${ }^{54}$. In the present study, all three genes targeted were present in $10^{4}$ copies/g dry wt of sediment, suggesting that multiple factors control anammox gene distribution within sediment ODZ. For hzo gene targeting non-Scalindua, no data in particular from marine sediments are reported. An available study from the eastern Indian Ocean ODZ sediments which focused mainly on Scalindua-specific 16S rRNA genes detected unusually high abundance, i.e. $3.20 \times 10^{4} \pm 1.18 \times 10^{3} \mathrm{ng}^{-1} \mathrm{DNA}^{36}$, while in the present study we retrieved only 9.6 copies $\mathrm{ng}^{-1}$ DNA. However in the methodology, these authors ${ }^{36}$ have not mentioned whether they used concentrated DNA or not.

For correlating gene abundance with bacterial abundance, it is essential to understand the copy number variation between the genes. The $16 \mathrm{~S}$ rRNA gene copy number varies significantly from 1 to 15 , an average being 3.6 copies per bacterial cell, making it a less suitable proxy for bacterial abundance estimation ${ }^{55}$. It is suggested that in anammox bacteria, 16S rRNA could be present in a single copy ${ }^{56}$. For $h z s \mathrm{~A}$ genes, the wholegenome study confirmed their occurrence in a single copy $^{5,57}$, whereas $h z s \mathrm{~B}$ and $h z s \mathrm{C}$ subunits occurred in multiple copies ${ }^{37}$. Hence $h z s \mathrm{~A}$ gene proves to be a better proxy for estimating anammox bacterial abundance. Accordingly, we assume that the actual anammox cell abundance in the studied site could be $\geq 4.99 \pm 0.35 \times 10^{4}$ copies/g dry wt of sediment, based on hzsA gene quantification. Few selected hzsA clones screened (unpublished data) showed that they must have been derived from an yet to be characterized anammox community. In the case of hzo also multiple copies are reported, but since there is not much information on the studied primer set hzo_cluster2, we cannot predict anything regarding the non-Scalind $u$ cell abundance ${ }^{4,21}$. It is possible that previous studies targeting the $16 \mathrm{~S}$ rRNA and hzo genes must have overestimated the anammox bacterial abundance, and we recommend obtaining data utilizing $h z s \mathrm{~A}$ gene.

Although a 2.4-fold higher value is reported ${ }^{58}$, the ratio of Scalindua $16 \mathrm{~S}$ rRNA to $h z s \mathrm{~A}$ was 1.38 -fold higher from the present study site. From this observation, it is possible to highlight that only $\leq 60 \%$ of hzs A might be from the Scalindua anammox community. The ratio of $h z o$ cluster2 to $h z s$ A was $\sim 0.71$-fold, suggesting that the non-Scalindua contribution could be $\geq 30 \%$. Unravelling the functional capability of these versatile communities is important and, accordingly, new primers must to be designed and tested to get a clear picture of the extent of diversity within the anammox community.

\section{Conclusion}

The present multi-gene, multi-primer-based study identifies vast diversity within the Candidatus Scalindua community and also provides realistic estimates of anammox abundance in the organic-rich sediments underlying the Arabian Sea hypoxic zones. It further highlights the applicability of functional genes and the advantages of using taxa-specific primers in diversity studies. For 


\section{RESEARCH ARTICLES}

understanding the factual diversity, similar profiling using novel and unique gene markers, and subsequent phylogenetic analysis is required to strengthen the database. Molecular signatures, if used correctly, could refine and contribute to many age-old concepts pertaining to anammox occurrence and dominance in the natural ecosystem.

Conflicts of interest: The authors declare no conflict of interest.

1. Lam, P. and Kuypers, M. M. M., Microbial nitrogen cycling processes in oxygen minimum zones. Annu. Rev. Mar. Sci., 2011, 3, 317-345.

2. Bulow, S. E., Rich, J. J., Naik, H. S., Pratihary, A. K. and Ward, B. B., Denitrification exceeds anammox as a nitrogen loss pathway in the Arabian Sea oxygen minimum zone. Deep-Sea Res. I: Oceanogr. Res., 2010, 57, 384-393.

3. Kuypers, M. M. et al., Massive nitrogen loss from the Benguela upwelling system through anaerobic ammonium oxidation. Proc. Natl. Acad. Sci. USA, 2005, 102, 6478-6483.

4. Kartal, B. et al., Molecular mechanism of anaerobic ammonium oxidation. Nature, 2011, 479, 127-130.

5. Harhangi, H. R. et al., Hydrazine synthase, a unique phylomarker with which to study the presence and biodiversity of anammox bacteria. Appl. Environ. Microbiol., 2012, 78, 752-758.

6. Dang, H., Zhou, H., Zhang, Z., Yu, Z., Hua, E., Liu, X. and Jiao, N., Molecular detection of Candidatus Scalindua pacifica and environmental responses of sediment anammox bacterial community in the Bohai Sea, China. PLoS ONE, 2013, 8, e61330.

7. Dalsgaard, T., Thamdrup, B. and Canfield, D. E., Anaerobic ammonium oxidation (anammox) in the marine environment. Res. Microbiol., 2005, 156, 457-464.

8. Griffiths, J. R. et al., The importance of benthic-pelagic coupling for marine ecosystem functioning in a changing world. Global Change Biol., 2017, 23, 2179-2196.

9. Barber, R. T. et al., Primary productivity and its regulation in the Arabian Sea during 1995. Deep-Sea Res. 2, 2001, 48(6-7), 1127-1172.

10. Van Mooy, B. A., Keil, R. G. and Devol, A. H., Impact of suboxia on sinking particulate organic carbon: enhanced carbon flux and preferential degradation of amino acids via denitrification. Geochim. Cosmochim. Acta, 2002, 66, 457-465.

11. Kalvelage, T. et al., Nitrogen cycling driven by organic matter export in the South Pacific oxygen minimum zone. Nature Geosci., 2013, 6, 228-234.

12. Jensen, M. M., Lam, P., Revsbech, N. P., Nagel, B., Gaye, B., Jetten, M. S. and Kuypers, M. M., Intensive nitrogen loss over the Omani Shelf due to anammox coupled with dissimilatory nitrite reduction to ammonium. ISME J., 2011, 5, 1660.

13. Strous, M. et al., Missing lithotroph identified as new planctomycete. Nature, 1999, 400, 446-449.

14. Schmid, M. et al., Molecular evidence for genus level diversity of bacteria capable of catalyzing anaerobic ammonium oxidation. Syst. Appl. Microbiol., 2000, 23, 93-106.

15. Schmid, M. et al., Candidatus 'Scalindua brodae', sp. Nov., candidatus 'Scalindua wagneri', sp. Nov., two new species of anaerobic ammonium oxidizing bacteria. Syst. Appl. Microbiol., 2003, 26, 529-538.

16. Kartal, B. et al., Candidatus 'Anammoxoglobus propionicus' a new propionate oxidizing species of anaerobic ammonium oxidizing bacteria. Syst. Appl. Microbiol., 2007, 30, 39-49.

17. Quan, Z. X. et al., Diversity of ammonium-oxidizing bacteria in a granular sludge anaerobic ammonium-oxidizing (anammox) reactor. Environ. Microbiol., 2008, 10, 3130-3139.
18. Viancelli, A. et al., Bacterial biodiversity from an anaerobic up flow bioreactor with anammox activity inoculated with swine sludge. Braz. Arch. Biol. Technol., 2011, 54, 1035-1041.

19. Khramenkov, S. et al., A novel bacterium carrying out anaerobic ammonium oxidation in a reactor for biological treatment of the filtrate of wastewater fermented sludge. Microbiology, 2013, 82, 628-636.

20. Sonthiphand, P., Hall, M. W. and Neufeld, J. D., Biogeography of anaerobic ammonia-oxidizing (anammox) bacteria. Front Microbiol., 2014, 5, 1-14.

21. Schmid, M. C. et al., Environmental detection of octahaem cytochrome $c$ hydroxylamine/hydrazine oxidoreductase genes of aerobic and anaerobic ammonium-oxidizing bacteria. Environ. Microbiol., 2008, 10, 3140-3149.

22. Li, M. and Gu, J.-D., Advances in methods for detection of anaerobic ammonium oxidizing (anammox) bacteria. Appl. Microbiol. Biotechnol., 2011, 90, 1241.

23. Bhushan, R., Dutta, K. and Somayajulu, B., Concentrations and burial fluxes of organic and inorganic carbon on the eastern margins of the Arabian Sea. Mar. Geol., 2001, 178, 95-113.

24. Azam, F. and Sajjad, M. H., Colorimetric determination of organic carbon in soil by dichromate digestion in a microwave oven. PJBS, 2005, 8, 596-598.

25. Bernard, B. B., Bernard, H. and Brooks, J. M., Determination of total carbon, total organic carbon and inorganic carbon in sediments. TDI-Brooks International/B\&B Labratories Inc, Texas, USA, 1995, pp. 1-5.

26. Nelson, D. and Sommers, L., Total carbon, organic carbon and organic matter. In Methods of Soil Analysis Part 2: Chemical and Microbiological Properties (ed. Page, A. L.), American Society of Agronomy, Soil Science Society of America, Madison (WI), USA, 1995, vol. 2, pp. 539-579.

27. Meyers, P. A., Preservation of elemental and isotopic source identification of sedimentary organic matter. Chem. Geol., 1994, 114, 289-302.

28. Plassart, P. et al., Evaluation of the iso standard 11063 DNA extraction procedure for assessing soil microbial abundance and community structure. PLoS ONE, 2012, 7, e44279.

29. Penton, C. R., Devol, A. H. and Tiedje, J. M., Molecular evidence for the broad distribution of anaerobic ammonium-oxidizing bacteria in freshwater and marine sediments. Appl. Environ. Microbiol., 2006, 72, 6829-6832.

30. Li, H., Chen, Shuo, Mu, Bo-Zhong and Gu, Ji-Dong, Molecular detection of anaerobic ammonium-oxidizing (anammox) bacteria in high-temperature petroleum reservoirs. Microb. Ecol., 2010, 60, $771-783$.

31. Wang, S. et al., Comparative analysis of two 16S rRNA genebased per primer sets provides insight into the diversity distribution patterns of anammox bacteria in different environments. Appl. Microbiol. Biotechnol., 2015, 99, 8163-8176.

32. Kong, L., Jing, H., Kataoka, T., Buchwald, C. and Liu, H., Diversity and spatial distribution of hydrazine oxidoreductase (hzo) gene in the oxygen minimum zone off Costa Rica. PLOS ONE, 2013, 8, e 78275 .

33. Pitcher, A., Villanueva, L., Hopmans, E. C., Schouten, S., Reichart, G. J. and Damsté, J. S. S., Niche segregation of ammoniaoxidizing archaea and anammox bacteria in the Arabian Sea oxygen minimum zone. ISME J., 2011, 5, 1896-1904.

34. Bandekar, M., Ramaiah, N. and Meena, R. M., Diversity and abundance of denitrifying and anammox bacteria from the Arabian Sea oxygen minimum zone. Deep-Sea Res 2, 2018, 156, 19-26.

35. Jasmin, C. et al., Diversity of sediment-associated planctomycetes in the Arabian Sea oxygen minimum zone. J. Basic Microbiol., 2017, 57, 1010-1017.

36. Qian, G. et al., Diversity and distribution of anammox bacteria in water column and sediments of the eastern Indian Ocean. Int. Biodeterior. Biodegradation, 2018, 133, 52-62.

CURRENT SCIENCE, VOL. 120, NO. 4, 25 FEBRUARY 2021 
37. Yang, Y., Li, M., Li, X.-Y. and Gu, J.-D., Two identical copies of the hydrazine synthase gene clusters found in the genomes of anammox bacteria. Int. Biodeterior. Biodegr., 2018, 132, 236240.

38. Prasad, V., Garg, R., Singh, V. and Thakur, B., Organic matter distribution pattern in Arabian Sea: palynofacies analysis from the surface sediments off Karwar coast (West Coast of India). IJMS, 2007, 36, 399-406.

39. Nair, R. et al., Increased particle flux to the deep ocean related to monsoons. Nature, 1989, 338, 749.

40. Rabalais, N., Diaz, R. J., Levin, L., Turner, R., Gilbert, D. and Zhang, J., Dynamics and distribution of natural and human-caused hypoxia. Biogeosciences, 2010, 7, 585.

41. Escobar-Briones, E. and García-Villalobos, F. J., Distribution of total organic carbon and total nitrogen in deep-sea sediments from the southwestern Gulf of Mexico. Bol. Soc. Geol. Mex., 2009, 61, $73-86$.

42. Sánchez, A., Distribution and composition of organic matter in sediments of the oxygen minimum zone of the northeastern Mexican Pacific: paleoceanographic implications/distribución y composición de la materia orgánica en sedimentos de la zona de oxígeno mínimo del pacífico nororiental mexicano: Implicaciones paleoceanográficas. J. Iber. Geol., 2013, 39, 111-120.

43. Paropkari, A. L., Babu, C. P. and Mascarenhas, A., A critical evaluation of depositional parameters controlling the variability of organic carbon in Arabian sea sediments. Mar. Geol., 1992, 107, 213-226.

44. Fu, L., Chen, Y., Li, S., He, H., Mi, T., Zhen, Y. and Yu, Z., Shifts in the anammox bacterial community structure and abundance in sediments from the changjiang estuary and its adjacent area. Syst. Appl. Microbiol., 2019, 42, 383-396.

45. Speth, D. R. and Jetten, M., Shotgun metagenomic data reveals significant abundance but low diversity of 'Candidatus Scalindua' marine anammox bacteria in the Arabian Sea oxygen minimum zone. Front. Microbiol., 2014, 5, 1-9.

46. Kuypers, M. M. et al., Anaerobic ammonium oxidation by anammox bacteria in the Black Sea. Nature, 2003, 422, 608-611.

47. Woebken, D. et al., A microdiversity study of anammox bacteria reveals a novel Candidatus Scalindua phylotype in marine oxygen minimum zones. Environ. Microbiol., 2008, 10, 3106-3119.

48. Hong, Y.-G., Li, M., Cao, H. and Gu, J.-D., Residence of habitatspecific anammox bacteria in the deep-sea subsurface sediments of the South China Sea: analyses of marker gene abundance with physical chemical parameters. Microb. Ecol., 2011, 62, 36-47.

49. Speth, D. R., Lagkouvardos, I., Wang, Y., Qian, P.-Y., Dutilh, B. E. and Jetten, M. S. M., Draft genome of Scalindua rubra, obtained from the interface above the discovery deep brine in the red sea, sheds light on potential salt adaptation strategies in anammox bacteria. Microb. Ecol., 2017, 74, 1-5.

50. Rich, J. J., Arevalo, P., Chang, B. X., Devol, A. H. and Ward, B. B., Anaerobic ammonium oxidation (anammox) and denitrification in Peru margin sediments. J. Mar. Syst., 2018, 207, 103-112.
51. Divya, B., Parvathi, A., Bharathi, P. L. and Nair, S., 16S rRNAbased bacterial diversity in the organic-rich sediments underlying oxygen-deficient waters of the eastern Arabian Sea. World J. Microbiol. Biotechnol., 2011, 27, 2821-2833.

52. Kumar, M., Daverey, A., Gu, J.-D. and Lin, J.-G., Anammox processes. In Current Developments in Biotechnology and Bioengineering (eds Larroche, C. M., Du, S. N. and Ashok Pandey, A.), Elsevier, The Netherlands, 2017, pp. 381-407.

53. Lipsewers, Y. A., Bale, N. J., Hopmans, E. C., Schouten, S., Sinninghe Damsté, J. S. and Villanueva, L., Seasonality and depth distribution of the abundance and activity of ammonia oxidizing microorganisms in marine coastal sediments (North Sea). Front Microbiol., 2014, 5, 1-12.

54. Bale, N. J., Villanueva, L., Fan, H., Stal, L. J., Hopmans, E. C., Schouten, S. and Sinninghe Damsté, J. S., Occurrence and activity of anammox bacteria in surface sediments of the southern North Sea. FEMS Microbiol. Ecol., 2014, 89, 99-110.

55. Kembel, S. W., Wu, M., Eisen, J. A. and Green, J. L., Incorporating $16 \mathrm{~S}$ gene copy number information improves estimates of microbial diversity and abundance. PLoS Comput. Biol., 2012, 8, e1002743.

56. Strous, M. et al., Deciphering the evolution and metabolism of an anammox bacterium from a community genome. Nature, 2006, 440, 790 .

57. Dietl, A. et al., The inner workings of the hydrazine synthase multiprotein complex. Nature, 2015, 527, 394.

58. Dang, H. et al., Environmental factors shape sediment anammox bacterial communities in hypernutrified Jiaozhou Bay, China. Appl. Environ. Microbiol., 2010, 76, 7036-7047.

59. Vieira, J. and Messing, J., The pUC plasmids, an M13mp7-derived system for insertion mutagenesis and sequencing with synthetic universal primers. Gene, 1982, 19, 259-268.

ACKNOWLEDGEMENTS. We thank Dr Amal Jayakumar and the anonymous reviewers for critical comments and suggestions that have helped improve the manuscript. We also thank the Director NIO, Goa for providing the required facilities. Mr Ram M. Meena (technical officer), for carrying out gene sequencing, and crew members of the SSD-014 cruise of $R V$ Sindhu Sadhana. This publication is NIO's contribution no: 6632. J.L. thanks the Council of Scientific and Industrial Research, New Delhi for fellowship grant 31/026(0245)/2012-EMR-I for doing Ph.D. This work is supported by CSIR grant: PSC0108 and OLP1707 support this work.

Received 18 May 2019; revised accepted 2 November 2020

doi: $10.18520 / \mathrm{cs} / \mathrm{v} 120 / \mathrm{i} 4 / 684-693$ 